\title{
Editorial expression of concern: Cdc6 expression is induced by HPV16 E6 and E7 oncogenes and represses E-cadherin expression
}

\author{
E. Faghihloo - M. Sadeghizadeh • S. Shahmahmoodi - T. Mokhtari-Azad
}

Published online: 6 February 2020

(c) The Author(s) 2020. This article is published with open access

\section{Addendum to: Cancer Gene Therapy}

https://doi.org/10.1038/cgt.2016.51

After careful review and discussions with the authors, the Editor-in-Chief is issuing an editorial expression of concern to alert readers that the cell lines used in this study [1] may have been contaminated. The data reported in this article should therefore be interpreted with caution. All authors agree with this notice.

Open Access This article is licensed under a Creative Commons Attribution 4.0 International License, which permits use, sharing, adaptation, distribution and reproduction in any medium or format, as long as you give appropriate credit to the original author(s) and the source, provide a link to the Creative Commons license, and indicate if changes were made. The images or other third party material in this article are included in the article's Creative Commons license, unless indicated otherwise in a credit line to the material. If material is not included in the article's Creative Commons license and your intended use is not permitted by statutory regulation or exceeds the permitted use, you will need to obtain permission directly from the copyright holder. To view a copy of this license, visit http://creativecommons. org/licenses/by/4.0/.

\section{Reference}

1. Faghihloo E, Sadeghizadeh M, Shahmahmoodi S, et al. Cdc6 expression is induced by HPV16 E6 and E7 oncogenes and represses E-cadherin expression. Cancer Gene Ther. 2016. https:// doi.org/10.1038/cgt.2016.51. 